\title{
ANOTASI BIBLIOGRAFI
}

\section{MEDIA PEMBELAJARAN,MODEL PEMBELAJARAN DAN PROFESI GURU}

Oleh:

Khairudi

Email:1910111210035@mhs.ulm.ac.id

Program Studi Pendidikan Sejarah Fakultas Keguruan dan llmu Pendidikan

Universitas Lambung Mangkurat

Banjarmasin

Susanto, H., \& Akmal, H. (2018). Efektivitas Penggunaan Aplikasi Pembelajaran Berbasis Mobile Smartphone Sebagai Media Pengenalan Sejarah Lokal Masa Revolusi Fisik Di Kalimantan Selatan Pada Siswa Sekolah Menengah Atas. HISTORIA: Jurnal Program Studi Pendidikan Sejarah, 6(2), 197-206.

Artikel ini mengkaji mobile smarthphone sebagai media pembelajaran yang menjadi acuan dalam pengenalan sejarah dengan menggunkan mobile smartphone ini lebih mempermudah dalam jangkauan untuk mempelajari sejarah lokal dimana dalam kehidupan sehari hari siswa maupun mahasiswa lebih sering menggunakan mobile smartphone dalam mencari referensi belajar oleh sebab itu artikel ini membahas apakah dengan mengaplikasikan mobile smartphone lebih mendorong siswa maupun mahasiswa dalam pengenalan sejarah lokal.’Pembahasan dalam artikel ini menguraikan tentang aspek aspek aplikatif yang dimana mengaplikasikan mobile smartphone dalam media pembelajaran dengan materi sejarah lokal masa revolusi fisik di kalimantan selatan. Dengan penggunaan mobile smartphone ini efektif dalam memberikan pemahaman dan pengenalan materi sejarah lokal kepada peserta didik pada sekolah menegah atas.

Mutiani, M., WARMANSYAH ABBAS, E. R. S. I. S., Syaharuddin, S., \& Susanto, H. (2019). Penerapan Transcript Based Lesson Analyses (TBLA) Sebagai Upaya Peningkatan Pembelajaran Sejarah Di Sma Negeri 7 Banjarmasin.

Artikel ini mengkaji penerapan Transcript Based Lesson Analyses (TBLA) $\begin{array}{lllllll}\text { Sebagai Upaya Peningkatan } & \text { Pembelajaran } & \text { Sejarah } & \text { Di } & \text { Sma } & \text { Negeri } & 7\end{array}$ Banjarmasin. Artikel ini menguraikan tentang penerapan TBLA dengan upaya peningkatan pembelajaran sejarah dengan mengunakan model ini apakah ada peningkatan kualitas guru dan peserta didik dalam pembelajaran sejarah dan juga pendekatan guru dan peserta didik dalam ruang lingkup belajar. Dalam artiekl ini, 
Penerapan model TBLA dalam pelajaran sejarah digunakan dua siklus, Kedua siklus didesain dengan menggunakan pendekatan saintifik model kooperatif.

Susanto, H. (2020). Profesi Keguruan.

Buku ini memilki tiga bab yang masing masing mempunyai pembahasan tentang profesi guru. Buku ini digunakan sebagai buku ajar yang menjadi rujukan dalam mencari informasi dan pemahaman terhadap profesi guru. Didalam buku ini membahas tentang konsep dasar profesi keguruan dari syarat profesi guru, kode etik profesi guru dan organisai profesi guru, kemudian membahas tentang sikap profesional keguruan dan kompentensi guru dengan terperinci dan yang terakhir membahas tentang perkembangan profesi guru dalam berbagai aspek, mulai dari aspek penegmbangan aktivitas insturksional, aspek pengembangan karir guru dan aspek pengembangan keprofesian.

\section{Simpulan Anotasi Bibliografi}

Media pembelajaran merupakan suatu hal penting dalam mencapai suatu tujuan pembelajaran, dimana saat ini perkembangan teknologi semkain tahun semakin maju sehingga guru dan dosen dituntut untuk dapat menguasai hal tersebut dengan maksud agar guru maupun dosen bisa memberikan pembelajaran yang lebih bisa di pahami oleh peserta didik melalui media pembelajaran. Pendidik bisa memberikan informasi dan pesan secara efektif dan efesien kepada peserta didik serta terjalin hubungan yang baik dari pendidik dan peserta didik dalam belajar dan mengajar di ruang lingkup sekolah. Jadi media pembelajaran salah satu metode yang bisa menyelesaikan macam-macam permasalahan yang terjadi di dalam belajar dan mengajar di ruang lingkup sekolah, dengan demikian peranan media pembelajaran sangat penting dalam penyampaian suatu informasi dan pesan kepada peserta didik agar tercapainya suatu tujuan pembelajaran di sekolah.

Kemudian dalam proses belajar dan mengajar perlu adanya pemilihan dan penggunan metode pembelajaran yang tepat sehingga peserta didik mudah memahami apa saja meteri yang diberikan oleh pendidik, melalui pemilihan metode pembelajaran yang tepat maka peserta didik tidak merasa bosan terhadap materi yang diberikan oleh guru sehingga peserta didik bisa meningkatkan pemahaman yang diberikan oleh pendidik dengan aktivitas belajar mengajar. Dengan demikian pemilhan dan penggunaan media pembelajaran dan pemilihan metode pembelajaran yang tepat menjadikan peserta didik lebih kreatif dan inovatif dalam belajar dan mengajar di 
ruang lingkup sekolah dan peserta didik memiliki kemampuan menangkap materi-materi yang diberikan oleh pendidik tersebut sehingga akan tercapai tujuan pembelajaran. Dengan demikian profesi guru memiliki andil besar dalam terjalannya sebuah pendidikan. Guru dituntut untuk bisa menggunakan media pembelajaran dan memilih metode pembelajaran yang tepat untuk dipakai dalam proses belajar mengajar secara efektif dan efesien. 